\title{
CONVENÇÃO PROCESSUAL SOBRE ÔNUS DA PROVA
}

\section{PROCEDURAL AGREEMENT ABOUT BURDEN OF PROOF}

\section{Leandro Ernani Freitag ${ }^{1}$}

Resumo: O presente artigo trata sobre o tema do ônus da prova e sua distribuição por meio de convenções processuais. Primeiramente, definem-se os conceitos de prova, dever e ônus. Traça-se uma evolução histórica, explanando a evolução do pensamento jurídico pátrio no que atine ao ônus da prova e à parte sobre quem deve recair, bem como a respeito de que fatos deve versar. Apresenta-se a teoria dinâmica do ônus da prova, com as consequências práticas de sua aplicação, cotejando-se o Código de Processo Civil de 1973 com o de 2015, atualmente vigente. Assim, objetiva-se situar o tema e compreender a interpretação que se dá à distribuição do ônus da prova. Após, estuda-se a convenção processual, com ênfase àquela relativa à distribuição do encargo probatório. Nesse ponto, o texto especifica os requisitos de validade da convenção processual sobre o ônus da prova, bem ainda, as consequências advindas do reconhecimento, pelo juiz, de sua invalidade.

Palavras-chave: Ônus da prova. Teoria dinâmica. Convenção processual.

Abstract: This work deals with the burden of proof theme and its distribution through procedural conventions. First it is defined the precepts of evidence, duty and burden. A historical evolution is traced, expounding the evolution of native juridical thought, regarding the burden of proof and to whom it may affect, as well as regarded to the facts it must relate to. It is presented the dynamic theory of the probationary burden of proof along with the practical consequences of its application. Comparing the Civil Procedure Code from 1973 to the Code of 2015 currently in force. This way the objective is to situate the theme and understand the interpretation given to the distribution of the burden of proof. The procedural

1 Juiz Substituto do Poder Judiciário do Estado de Santa Catarina (TJSC), lotado na $19^{\mathrm{a}}$ Circunscrição (Rio do Sul). Graduado em Direito pela Unoesc (2008). Especialista em Direito Constitucional (Uniderp - 2011); Direito Público e Privado: Material e Processual (Unoesc/Esmesc - 2013); Direito Penal e Processual Penal (UGF - 2013); Direito Civil (UGF - 2013); Direito Administrativo (UGF - 2013); Direito Tributário (AVM - 2015); Direito Processual Civil (Unyleya - 2017). E-mail: lefreitag@tjsc.jus.br. 
convention is studied emphasizing that related to the distribution of probationary encumbrance. At this point the text specifies the requirements of procedural convention validation over the burden of proof. As well as the consequences stemming from the recognition of the judge in its invalidation.

Keywords: Burden of Proof. Dynamic Theory. Procedural Agreement.

\section{INTRODUÇÃO}

O presente estudo destina-se a analisar a aplicabilidade e validade da convenção processual que versa sobre a distribuição do ônus da prova.

O encargo relacionado à produção da prova, tradicionalmente, era distribuído de modo prévio e abstrato, de modo genérico, a quem fizesse a alegação; ou seja, quem alega deve provar.

Contudo, o avanço da sociedade e o consequente incremento do grau de complexidade das causas discutidas judicialmente revelaram, paulatinamente, que tal critério de distribuição do ônus probatório se mostrava insuficiente ou inadequado para uma resolução criteriosa de um número cada vez maior de situações, cenário no qual surgiu a teoria da distribuição dinâmica do ônus da prova, pela qual é possível que o julgador distribua de modo diverso do tradicional o encargo de produzir a prova.

Por outro lado, a convenção processual (ou negócio jurídico processual), espécie de acordo entre as partes que, não versando sobre o mérito da demanda, trata sobre aspectos procedimentais da ação proposta em juízo, ganhou força e relevância com o Código de Processo Civil de 2015 - que alterou a visão tradicional, de protagonismo do julgador, para uma concepção mais moderna, de solidariedade e cooperação entre partes e juiz. E uma de suas possibilidades - conquanto já timidamente permitida pela legislação anterior - é convencionarem as partes, a seu critério, distribuir o ônus da prova a um deles, vinculando, com isso - ao menos em tese - , o Estado-juiz, responsável por dizer o direito no caso concreto.

Assim, o estudo ora apresentado procura responder a seguin- 
te indagação: quais são os requisitos de aplicabilidade e validade do negócio jurídico processual sobre distribuição do ônus probatório, e quais as consequências da invalidade de tal convenção?

A pesquisa far-se-á pela forma qualitativa, utilizando-se análise e interpretação de dados e de fontes bibliográficas, com o objetivo de compreender a questão posta e apresentar uma solução para o problema. $\mathrm{O}$ método pelo qual se desenvolve a pesquisa é o dialético, de modo que são expostas e debatidas as argumentações e contra-argumentações a respeito da questão, a fim de se atingir uma síntese do assunto.

\section{O ÔNUS DA PROVA NO PROCESSO CIVIL BRASILEIRO}

Passa-se, inicialmente, a efetuar algumas definições e distinções necessárias ao desenvolvimento do presente estudo. $\mathrm{O}$ vocábulo prova vem do latim probatio, que significa verificação, exame, inspeção; juridicamente, o termo assume múltiplas significações. Como anota Rangel (apud PAOLINELLI, 2014, p. 40-41), o termo pode significar:

a) a prova como actividade probatória (ou instrutória) é a actividade (actos processuais) dirigida aos fins próprios da instrução; b) a prova como resultado (resultado probatório) é a demonstração efectiva (segundo a convicção do juiz da realidade dum facto), da veracidade da correspondente afirmação, designando ainda os dados fornecidos pela actividade probatória, mesmo que não conduzam à efectiva demonstração dos fatos visados; nesta visão fala-se, também de material probatório (Beweis-Toff); c) a prova como motivo ou argumento probatório, (Beweisgrund) representa qualquer elemento (do material probatório) que tenha produzido a convicção do juiz, qualquer razão determinante dessa convicção.

No primeiro conceito acima (prova como atividade), temse a ideia de procedimento probatório, o qual corresponde aos atos efetivados pelas partes ou pelo órgão jurisdicional, 
relativamente à produção da prova. No segundo (prova como resultado), a prova é entendida como o resultado final do procedimento probatório, como fator de influência para a prolação da decisão judicial. Já no terceiro (prova como meio), fala-se da forma pela qual os fatos são provados em juízo, ou melhor, da maneira que, no caso concreto, a parte utiliza para comprovar a ocorrência dos fatos: prova testemunhal, pericial etc.

Mais especificamente no que se refere ao comportamento das partes em relação ao processo, tem-se os conceitos de ônus e dever. Conquanto as duas ideias digam respeito a uma determinada atitude da parte, pode-se diferenciá-las quanto ao interesse em jogo e quanto à consequência do descumprimento.

Assim, o ônus é um imperativo do interesse da própria parte a que se refere, e seu descumprimento não gera, por si só, um direito à contraparte. Isto é, o ônus é um "peso" que se impõe sobre uma parte para que ela possa se desincumbir dele, "[...] transmitindo uma ideia relacionada a situações de necessidade de realizar determinado ato para evitar que sobrevenha um prejuízo processual, referindo-se ao aproveitamento de uma possibilidade que beneficiará a parte diligente" (LOURENÇO, 2015, p. 27).

Ou seja, o ônus não gera uma obrigação, pois não há sujeição da parte; ela pode decidir entre se desincumbir ou não do ônus e, optando pela negativa, deverá arcar com as consequências. Por isso é que, por exemplo, contestar ou produzir provas são ônus: são atividades ligadas à esfera de interesse da própria parte, que não pode ser obrigada a tanto. Entretanto, deixar de contestar ou de provar pode redundar em prejuízo - como a revelia ou o julgamento em sentido contrário, respectivamente.

O dever, por outro lado, está umbilicalmente conectado à sujeição do indivíduo a interesse alheio; descumprido, gera para ela o direito de exigir uma determinada conduta - por exemplo, o desfazimento ou reparação do dano. Nesse sentido, v.g., todo 
aquele que participa do processo deve comportar-se de acordo com a boa-fé (art. 5, CPC/2015); tal dever geral de conduta, se descumprido, poderá acarretar penalização do infrator (arts. 80 e 81, CPC/2015). Nessa hipótese, ao contrário do ônus, a conduta de quem infringe um dever processual acarreta dano à outra parte; portanto, ela pode ser obrigada a comportar-se de modo diverso, existindo, pois, uma situação de sujeição de interesses.

Por isso, é possível visualizar que o encargo de provar não é, em verdade, um dever, já que a parte não é obrigada a instrumentalizar a produção de provas. Sujeita-se, conduto, aos riscos de tal inércia, especialmente os relativos ao resultado do julgamento, pelo que constitui, de fato, um ônus processual.

\subsection{A importância da definição do ônus da prova}

Não é dada ao Estado-juiz a possibilidade de se escusar do poder-dever de decidir; isto é, ainda que a parte que deveria ter produzido a prova não consiga satisfatoriamente fazê-lo, não poderá o julgador deixar aplicar o direito alegando falta de clareza (vedação ao non liquet), ou mesmo ausência de norma legal a reger o caso em específico - nesse sentido determinam os artigos 126 e 1240 dos anteriores Códigos de Processo Civil (BRASIL, 1973; BRASIL, 2015). Ademais, como observa Lourenço (2015, p. 30), o non liquet nem poderia ser uma opção, pois a Lei Maior determina a inafastabilidade da jurisdição (art. $5^{\circ}, \mathrm{XXXV}$ ).

Consequentemente, há necessidade de se estabelecerem critérios para a solução de casos em que a parte não se desincumba da responsabilidade de produzir provas idôneas a formar o convencimento do juiz.

Dessarte, quanto à questão fática controvertida, o critério previsto na legislação é justamente o do ônus da prova. Sintetizando, pode-se afirmar que, se a prova produzida não é firme e robusta a ponto de servir para lastrear a convicção do julgador, a decisão será então proferida de modo contrário aos interesses 
de quem tinha o ônus de provar. E é exatamente nesse ponto que reside a importância de a lei estabelecer parâmetros para a distribuição do ônus probatório, despontando a teoria estática e a teoria dinâmica, como se verá a seguir.

\subsection{A teoria estática do ônus da prova e suas consequências}

Tradicionalmente, o sistema jurídico brasileiro albergava apenas a teoria estática da distribuição do ônus probatório, $o$ que significa dizer que a lei processual definia a quem cabia o encargo de provar, sem possibilidade de alteração pelo órgão jurisdicional. No Código de Processo Civil anterior (BRASIL, 1973), o tema era assim tratado:

Art. 333. O ônus da prova incumbe:

I - ao autor, quanto ao fato constitutivo do seu direito;

II - ao réu, quanto à existência de fato impeditivo, modificativo ou extintivo do direito do autor.

Parágrafo único. É nula a convenção que distribui de maneira diversa o ônus da prova quando:

I - recair sobre direito indisponível da parte;

II - tornar excessivamente difícil a uma parte o exercício do direito.

Assim, o ônus probatório era definido de modo prévio e abstrato, seguindo a regra geral "a prova incumbe a quem afirma" (affirmanti incumbit probation), ligada ao princípio dispositivo, que confere principalmente às partes a iniciativa e responsabilidade na produção de provas. Dessa maneira, o autor, alegando seu direito, deveria provar os fatos constitutivos; o réu, por sua vez, ao alegar fatos impeditivos, modificativos ou extintivos do direito do autor, deveria prová-los. O parágrafo único do dispositivo, lado outro, já permitia a distribuição diversa, por convenção das partes. 
Portanto, o CPC de 1973 distribuía o ônus da prova com base na natureza dos fatos probandos e na posição das partes em juízo, abraçando, assim, como ensina Pacífico (2011, p. 106), posição sustentada por Chiovenda, Carnelutti e Betti, possuindo nítida influência do Código Civil Napoleônico. Dessa forma, a posição da parte (autor $\mathrm{X}$ réu) e a espécie de fato alegado (constitutivo $\mathrm{X}$ impeditivo, modificativo ou extintivo) é que determinam, no âmbito de aplicação de tal teoria, a quem incumbe o ônus probatório, inexistindo hipótese de alteração pelo juiz. Entretanto, tal vertente da teoria estática não resistiu ao passar do tempo, e paulatinamente passou a ser não substituída, mas complementada, por outra teoria.

\subsection{A teoria dinâmica do ônus da prova}

O incremento da complexidade da vida em uma sociedade globalizada e, consequentemente, dos casos a serem decididos judicialmente, revelaram que a teoria estática da distribuição do ônus da prova não mais era capaz de adequadamente solver toda a gama de conflitos existentes.

Em verdade, a doutrina não poupa críticas à teoria estática: diz-se, por exemplo, que ela está muito mais preocupada com a decisão judicial do que com a tutela do direito substancial lesado ou ameaçado de lesão (CAMBI, 2016, p. 249). Afirma-se, ainda, que a distribuição rígida do ônus da prova atrofia o sistema, e sua aplicação inflexível pode conduzir a julgamentos injustos (DIDIER JUNIOR et al. apud BAZZANEZE, 2012, p. 63). A distribuição estática encerra potencial e relevante risco de produção de decisões injustas, tendo em vista que, muitas vezes, a parte que alega não possui as melhores ou mais propícias condições técnicas ou fáticas para produzir determinada prova.

Assim, no sistema jurídico brasileiro, houve relevante alteração quanto ao tema do encargo de provar com o advento do Código de Defesa do Consumidor (Lei n. 8.078/90), o qual, 
em dois dispositivos, alterou a regra prevista na lei geral. Com efeito, o art. $6^{\circ}$, VIII, permite a inversão do ônus em favor do consumidor, "[...] quando, a critério do juiz, for verossímil a alegação ou quando for ele hipossuficiente, segundo as regras ordinárias de experiências" (BRASIL, 1990); e o art. 38, por sua vez, especificamente no pertinente à publicidade, determina que o ônus da prova, nesse particular, cabe a quem a patrocina.

Em continuidade à evolução do pensamento jurídico nessa seara, interpretou-se que a inversão do ônus probatório prevista no Código de Defesa do Consumidor pode ser aplicável a outras temáticas. Isso porque diferentes leis não se excluem, por pertencerem a ramos jurídicos distintos, mas sim se complementam, em especial quando possuem campos de aplicação comuns ou convergentes.

Assim, de acordo com a teoria do diálogo das fontes, existe verdadeira interação entre diversos diplomas legislativos, dentro do chamado "microssistema processual coletivo", permitindo a interpretação no sentido de que todas essas leis fazem parte de um mesmo microssistema, e devem ser interpretadas harmônica e conjuntamente; nesse passo, o art. 21 da Lei n. 7.347/85 expressamente determina que "aplicam-se à defesa dos direitos e interesses difusos, coletivos e individuais, no que for cabível, os dispositivos do Titulo III da lei que instituiu o Código de Defesa do Consumidor", enquanto que o art. 90 do CDC prevê que "aplicam-se às ações previstas neste título as normas do Código de Processo Civil e da Lei n ${ }^{\circ} 7.347$, de 24 de julho de 1985, inclusive no que respeita ao inquérito civil, naquilo que não contrariar suas disposições" (BRASIL, 1990), em verdadeiras "normas de reenvio", ou seja, determinando a aplicação de mais de uma lei concomitantemente.

Como consequência, entende-se, por exemplo, que a inversão do ônus probatório prevista no CDC aplica-se também à seara ambiental, espécie de direito difuso por excelência, de 
maneira que não é preciso ao autor provar o dano, mas sim ficando a cargo do poluidor comprovar que sua atividade não resulta em danos para o meio ambiente - em interpretação que privilegia, ainda, o princípio da precaução, cujo intuito é maximizar a proteção do ambiente, ainda que o dano concreto seja incerto ou desconhecido. A respeito:

PROCESSUAL CIVIL E AMBIENTAL - AÇÃO CIVIL PÚBLICA - DANO AMBIENTAL - ADIANTAMENTO DE HONORÁRIOS PERICIAIS PELO PARQUET - MATÉRIA PREJUDICADA - INVERSÃO DO ÔNUS DA PROVA - ART. 6º, VIII, DA LEI 8.078/1990 C/C O ART. 21 DA LEI 7.347/1985 - PRINCÍPIO DA PRECAUÇÃO. [...]3. Justifica-se a inversão do ônus da prova, transferindo para o empreendedor da atividade potencialmente perigosa o ônus de demonstrar a segurança do empreendimento, a partir da interpretação do art. $6^{\circ}$, VIII, da Lei 8.078/1990 c/c o art. 21 da Lei 7.347/1985, conjugado ao Princípio Ambiental da Precaução. 4. Recurso especial parcialmente provido (STJ, REsp 972.902/ RS, Rel. Min. Eliana Calmon, $2^{\mathrm{a}}$ Turma, j. 25/8/2009).

Toda essa evolução doutrinaria e jurisprudencial, de certa forma, "preparou o terreno" para uma mudança ainda mais radical no esquema de distribuição do ônus probatório. Primeiramente, na história jurídica pátria, ele foi estático, distribuído a priori, sem possibilidade de alteração pelo julgador; depois, passou a admitir inversão, no caso de questões consumeristas; e em seguida, permitiu, por meio da teoria do diálogo das fontes, a aplicação da regra para casos inicialmente não por ela previstos expressamente (como, por exemplo, no Direito Ambiental, para proteger de modo mais efetivo o meio ambiente); a temática do ônus da prova atinge o ápice com a teoria da distribuição dinâmica do ônus da prova.

O termo dinâmica é empregado justamente para demonstrar que, nessa visão, a questão de a quem incumbe o ônus da prova não está definida de modo pronto e acabado pela lei, mas sim comporta possibilidade de alteração (ainda que excepcio- 
nal), pelo Estado-juiz, de acordo com certos requisitos legais.

Portanto, em suma, para tal teoria, permite-se o deslocamento do ônus de provar, pelo julgador, conforme as circunstâncias do caso concreto, onerando a parte que possuir melhores condições técnicas, profissionais ou fáticas para produzir a prova de um determinado fato. Ou seja, não mais importa a posição processual da parte (como autor ou réu na demanda) ou ainda a modalidade de fato (constitutivo, para o autor, ou impeditivo, modificativo ou extintivo de direitos, para o réu), mas sim as nuances do caso em específico.

Como afirma Silveira (2016, p. 215 e 219), a distribuição dinâmica, em última análise, é, assim, mais consentânea ao Processo Civil no Estado Constitucional; possui fundamento maior no princípio do devido processo legal, e encontra raízes no acesso à justiça, no direito à prova, no direito à igualdade $\mathrm{e}$ nos deveres de cooperação.

Muito embora tenha sido com o advento do Código de Processo Civil de 2015 que a teoria da distribuição dinâmica do ônus da prova tenha sido prevista, ela já vinha sendo aplicada há relevante lapso de tempo antes de sua vigência, como se pode ver, v.g., do seguinte julgado, do ano de 2013:

CIVIL E PROCESSO CIVIL. PEDIDO. INTERPRETAÇÃO. CRITÉRIOS. PROVA. ÔNUS. DISTRIBUIÇÃO. LITIGÂNCIA DE MÁ FÉ. COBRANÇA DE DÍVIDA JÁ PAGA. LIMITES DE INCIDÊNCIA. DISPOSTIVOS LEGAIS ANALISADOS: ARTS. 17, 18, 125, I, 282, 286, 333, I E II, 339, 355, 358, 359, 460 E 512 DO CPC; E 1.531 DO CC/16 (940 DO CC/02).[...] 6. Nos termos do art. 333, II, do CPC, recai sobre o réu o ônus da prova da existência de fato impeditivo, modificativo ou extintivo do direito do autor. 7. Embora não tenha sido expressamente contemplada no CPC, uma interpretação sistemática da nossa legislação processual, inclusive em bases constitucionais, confere ampla legitimidade à aplicação da teoria da distribuição dinâmica do ônus da prova, segundo a 
qual esse ônus recai sobre quem tiver melhores condições de produzir a prova, conforme as circunstâncias fáticas de cada caso. [...](STJ, REsp 1286704/SP, Rel. Ministra Nancy Andrighi, $3^{\text {a }}$ Turma, j. 22/10/2013, grifo nosso).

Por conseguinte, o mérito do $\mathrm{CPC} / 2015$, muito embora não resida em propriamente inaugurar a aplicação da teoria em solo pátrio, consiste em fixar balizas seguras para sua aplicação, bem como em extirpar qualquer dúvida que ainda pudesse residir acerca de seu cabimento no sistema jurídico brasileiro.

O tema é regulamentado pelo atual diploma processual civil do seguinte modo:

Art. 357. Não ocorrendo nenhuma das hipóteses deste Capítulo, deverá o juiz, em decisão de saneamento e de organização do processo: [...]

III - definir a distribuição do ônus da prova, observado o art. $373 ;[\ldots]$

Art. 373. O ônus da prova incumbe:

I - ao autor, quanto ao fato constitutivo de seu direito;

II - ao réu, quanto à existência de fato impeditivo, modificativo ou extintivo do direito do autor.

$\S 1^{\circ}$ Nos casos previstos em lei ou diante de peculiaridades da causa relacionadas à impossibilidade ou à excessiva dificuldade de cumprir o encargo nos termos do caput ou à maior facilidade de obtenção da prova do fato contrário, poderá o juiz atribuir o ônus da prova de modo diverso, desde que o faça por decisão fundamentada, caso em que deverá dar à parte a oportunidade de se desincumbir do ônus que lhe foi atribuído.

$\S 2^{\circ} \mathrm{A}$ decisão prevista no $\S 1^{\circ}$ deste artigo não pode gerar situação em que a desincumbência do encargo pela parte seja impossível ou excessivamente difícil.

$\S 3^{\circ}$ A distribuição diversa do ônus da prova também pode ocorrer por convenção das partes, salvo quando:

I - recair sobre direito indisponível da parte; 
II - tornar excessivamente difícil a uma parte o exercício do direito.

$\S 4^{\circ}$ A convenção de que trata o $\S 3^{\circ}$ pode ser celebrada antes ou durante o processo (BRASIL, 2015).

De acordo com Silveira (2016, p. 228), o ponto apresenta cinco principais características: a) regra geral; b) momento processual adequado; c) a quem e quando deve ser modificado o ônus probatório; d) prova diabólica reversa como obstáculo; e e) papel da hipossuficiência econômica na distribuição do ônus.

Quanto à existência de uma regra geral, é de se frisar que, como o objetivo da técnica é trazer aos autos uma prova relevante para o julgamento da lide, que, pela regra geral(teoria estática), provavelmente não teria sido produzida, a modificação do ônus probatório somente deve se dar em casos excepcionais. Ou seja, "não se deve pretender transformar a modificação do ônus em regra, afastando a aplicação da regra geral, que é a distribuição legal e não pelo juiz" (SILVEIRA, 2016, p. 215). Portanto, somente nos casos extremos, em que as peculiaridades do caso revelam que não seria a questão resolvida a contento com a regra geral, tem lugar a teoria dinâmica.

$\mathrm{O}$ momento processual adequado para eventual redistribuição do ônus deve ser, conforme art. 357, III, do CPC/2015 c/c art. $373, \S 1^{\circ}$, parte final, a decisão de saneamento do processo; ou, ao menos, em momento que possibilite à parte se desincumbir do ônus, o que impede que o magistrado faça a modificação apenas na sentença, corrente que prevaleceu na doutrina e jurisprudência (v.g., STJ, AgRg no REsp 1450473/SC, Rel. Ministro Mauro Campbell Marques, $2^{\mathrm{a}}$ Turma, j. 23/9/2014), interpretando-se a alteração como regra de saneamento - e não de julgamento - , por uma questão de lealdade processual e para evitar que a parte seja surpreendida com a modificação apenas na sentença.

Acerca de a quem e quando o ônus deve ser modificado, 
são critérios: (1) a previsão legal (como no caso do CDC); (2) a extrema dificuldade ou impossibilidade na produção da prova pela parte que originariamente teria o ônus; e (3) as melhores condições da parte adversa na produção da prova. A situação de dificuldade ou impossibilidade, contudo, deve ser real e séria, a ponto de prejudicar consideravelmente a parte, ou de fato impedir que ela consiga produzir a prova. Como afirma Silveira (2016, p. 215), "para que se autorize a modificação do ônus da prova não se pode estar de simples dificuldade, mas uma dificuldade grave, real, que possa ser caracterizada como violadora do direito à prova constitucionalmente garantido", o que deverá ser verificado pelo julgador caso a caso.

O conceito de prova diabólica está ligado a afirmações impossíveis de serem provadas, por inexistirem meios de se comprovar a alegação - geralmente, fatos negativos indefinidos. Por exemplo, é impossível provar que certa pessoa nunca esteve no Estado de Santa Catarina. Contudo, se for fato negativo definido, pode ser provado por via indireta (uma pessoa pode provar que não estava no Rio de Janeiro em certo dia e hora porque, naquele momento, encontrava-se em Brasília). Nesse contexto, a dinamização do ônus probatório não pode redundar em prova diabólica reversa, ou seja, não se pode retirar o ônus da prova de uma parte para atribuí-la a outra se esta, por sua vez, também não terá meios de produzir tal prova. Por conseguinte, a prova diabólica reversa funciona como limite da dinamização no caso concreto, somente devendo ocorrer a modificação se a parte a quem se atribui o ônus realmente tem maior facilidade ou possibilidade de produzir a prova pertinente.

Por fim, quanto à hipossuficiência econômica da parte como parâmetro relevante para a dinamização, tem-se que, ao menos em tese, tal fator não deve servir para dinamizar o ônus probatório. Isso porque a lei processual já prevê meios próprios para possibilitar o acesso à justiça para os hipossuficientes, como a 
gratuidade da justiça (art. 98), a qual engloba, por exemplo, honorários periciais (art. 98, $\S 1^{\circ}$, VI). A situação econômica da parte, assim, não impede nem dificulta a produção da prova, que será, ao fim e ao cabo, produzida da mesma forma ${ }^{2}$. No mesmo sentido, Macêdo e Peixoto (2016, p. 206) afirmam que "a forma adequada para resolver o problema dos custos das provas não é a dinamização do ônus da prova. Ela não tem essa função" - justamente porque é à justiça gratuita a quem incumbe tal papel. Não se pode deixar de registrar, entretanto, que há corrente doutrinária em sentido divergente, para quem razões econômicas justificariam a dinamização do ônus da prova (CREMASCO, 2012, p. 86 apud SILVEIRA, 2016, p. 245).

Assim, após a análise da aplicabilidade da dinamização do ônus probatório, passa-se, na sequência, a estudar a questão da sua regulamentação pelas partes, seus requisitos, bem ainda, as consequências da invalidade da convenção.

\section{CONVENÇÃO PROCESSUAL SOBRE DISTRIBUIÇÃO DO ÔNUS DA PROVA}

O processo é uma sequência de atos destinada a um objetivo determinado e, especificamente com relação ao processo judicial, sua finalidade é a sentença. De fato, em última análise, o fim é a

2 Registre-se que o enunciado n. 26 da Súmula do Tribunal de Justiça de Santa Catarina dispõe que: "Nas demandas de competência civil-consumerista, sendo o autor beneficiário da justiça gratuita, deve o réu arcar com o pagamento prévio de metade do valor dos honorários periciais nas hipóteses em que a produção da prova técnica for requerida por ambos os litigantes ou exclusivamente pelo autor, ou, ainda, determinada de ofício pelo juiz". No entanto, o enunciado data de 2014 - ou seja, é anterior ao Código de Processo Civil de 2015, que possui regramento específico sobre o ponto (art. $95, \S 3^{\circ}$ ). De mais a mais, posteriormente, em território catarinense, a Lei Complementar Estadual n. 188/1999, com a redação dada pela Lei Complementar Estadual n. 730/2018, determinou a utilização de verbas do Fundo de Reaparelhamento da Justiça para custeio dos honorários periciais devidos pelos beneficiários de justiça gratuita, o que foi regulamentado pelo Tribunal de Justiça através da Resolução CM 5/2019. Assim, em suma, a hipótese não mais transparece necessidade de que a parte ré arque com metade do valor da perícia quando apenas o autor a pleiteou, mas tão somente demanda aplicação da citada normatização - que determina o pagamento dos honorários periciais mediante requisição ao Fundo, sem olvidar a possibilidade de ulterior ressarcimento pela Fazenda Pública (art. 95, § 4, CPC). 
pacificação social justa atingida, ao menos em tese, com a sentença.

Dessarte, se, por um lado, é certo que o Estado possui interesse no processo - pois é através dele que é dito o direito aplicável no caso concreto, solucionando em definitivo a lide entre as partes - , não se pode deixar de lado que os maiores interessados no processo são as partes: afinal, é o direito delas que é debatido e, ao final, decidido nos autos.

Desde a concepção inicial das normas sobre processo, como observam Ponte e Romão (2015), entendeu-se que sua natureza jurídica é de direito público, pois tratam sobre uma relação jurídica existente entre o Estado e os particulares. Isso fez com que fossem vistas como cogentes, não permitindo ingerência das partes sobre sua aplicação. Assim, tradicionalmente, eram praticamente inexistentes as possibilidades que as partes tinham de modificar a incidência das normas processuais, podendo-se destacar, do CPC de 1973, a alteração de prazos dilatórios (art. 181), o adiamento de audiência (art. 453, I), a suspensão do processo (art. 265, II), a eleição de foro (art. 111), e, também, a modificação da distribuição do ônus probatório (art. 333, parágrafo único, a contrario sensu).

O Código de Processo Civil de 2015, entretanto, apresenta um avanço dessa visão restrita. Com efeito, se antes o protagonista era o juiz, que julgava e administrava os interesses das partes, agora, com a preocupação do legislador em positivar o princípio da cooperação (art. $6^{\circ}$ ), todos assumem o protagonismo, devendo atuar juntos - cada qual, por certo, com sua visão e sem abandonar seu papel, mas todos para o mesmo fim.

De forma consentânea com essa nova percepção do processo judicial, ganha relevo a autonomia privada, vista historicamente como uma "intrusa" no Processo Civil, mas agora assumindo papel de relevância; com o CPC/2015 e a previsão explícita das negociações processuais, “[...] dá-se um imenso passo para que efe- 
tivamente se reconheça a existência de um princípio do respeito ao autorregramento da vontade" (GODINHO, 2015, p. 114).

Sendo assim, em respeito, portanto, ao interesse das partes, e reconhecendo sua possibilidade de ajustarem determinados aspectos da marcha processual, o novel diploma processual civil expressamente prevê as convenções processuais (também denominadas negócios jurídicos processuais), as quais podem ser entendidas como sendo:

[...] todos os atos bilaterais praticados no curso do processo ou para nele produzirem efeitos, que dispõem sobre questões do processo, subtraindo-as da apreciação judicial ou condicionando o conteúdo de decisões judiciais subsequentes. O que caracteriza as convenções processuais ou é a sede do ato - ato integrante da relação processual, praticado no processo - , ou é a sua finalidade de produzir efeitos em determinado processo, presente ou futuro (GRECO, 2007).

Faz-se mister frisar que a convenção processual não se confunde com os atos das partes que versem sobre o mérito do processo (como transação, renúncia ou reconhecimento jurídico do pedido, por exemplo), justamente porque não tratam sobre o direito discutido, mas sim sobre a dinâmica da tramitação processual.

Quanto à abrangência dessa cláusula geral de flexibilização procedimental, poderão ser alvo de negociação, conforme Ponte e Romão (2015): (1) os atos processuais praticados pelas partes; (2) a forma revestida pelos atos, englobando o local e o momento de sua realização; (3) a conveniência e a oportunidade dos comportamentos dos sujeitos processuais; (4) a ordem das fases e dos atos processuais; e (5) a espécie de procedimento a ser adotada.

Nessa esteira, tanto o CPC de 2015, quanto o anterior, privilegiando a possibilidade de autorregramento processual pelas próprias partes, admitem a convenção processual sobre a distribuição do ônus probatório, obedecidos determinados parâmetros. 


\subsection{Requisitos de validade da convenção sobre distribuição do ônus da prova}

Há, ao longo do CPC/2015, previsões específicas acerca de possíveis convenções processuais das partes - como, por exemplo, escolha de perito (art. 471), suspensão do processo (art. 313, II), eleição de foro (art. 63) e calendarização de atos (art. 191). Em seus termos gerais, todavia, o ponto é regulamentado pelo diploma processual civil atualmente vigente da seguinte forma:

Art. 190. Versando o processo sobre direitos que admitam autocomposição, é lícito às partes plenamente capazes estipular mudanças no procedimento para ajustá-lo às especificidades da causa e convencionar sobre os seus ônus, poderes, faculdades e deveres processuais, antes ou durante o processo.

Parágrafo único. De ofício ou a requerimento, o juiz controlará a validade das convenções previstas neste artigo, recusando-lhes aplicação somente nos casos de nulidade ou de inserção abusiva em contrato de adesão ou em que alguma parte se encontre em manifesta situação de vulnerabilidade.

$[\ldots]$

Art. 200. Os atos das partes consistentes em declarações unilaterais ou bilaterais de vontade produzem imediatamente a constituição, modificação ou extinção de direitos processuais (BRASIL, 2015).

A distribuição do ônus probatório por negócio jurídico processual revela um ato típico, ante a previsão legal expressa, e pode se dar de modo unilateral - mediante manifestação de vontade de apenas uma das partes, suficiente para assunção do ônus da prova, com as consequências respectivas - , ou bilateral - por meio da manifestação das vontades de ambas, de forma convergente, recíproca e concordante sobre o ponto em questão. Pode, ainda, ocorrer em sede judicial ou extrajudicial, mas sempre observando a boa-fé objetiva, "[...] visando a evitar o comportamento contraditório da parte a quem beneficie a inversão do ônus da prova" (MOUZALAS; ATAÍDE JÚNIOR, 2015, p. 403). 
A liberdade, como se vê dos dispositivos legais citados, é limitada; não pode o Estado permitir que as partes tenham poderes irrestritos e disponham, em absoluto, sobre a forma pela qual deve tramitar o processo judicial - até porque a presença estatal, com a necessidade de aparelhamento adequado e funcionamento de acordo com o interesse público, não permite uma amplitude total da regulação do processo, como, em tese, ocorreriaem uma celebração negocial típica de direito privado; "dizer que a liberdade é limitada, no entanto, não equivale a negá-la” (MACÊDO; PEIXOTO, 2016, p. 119).

Portanto, aos requisitos de validade dos negócios jurídicos em geral (conforme art. 104 do Código Civil: agente capaz, objeto lícito, possível, determinado ou determinável, forma prescrita ou não defesa em lei), somam-se outros específicos. Para Greco (2007), a definição dos limites entre os poderes do juiz e a autonomia das partes está diretamente ligada a três fatores: a) disponibilidade do direito material posto em juízo; b) equilíbrio entre as partes e paridade de armas; e c) observância dos princípios e garantias fundamentais do processo no Estado Democrático de Direito.

O primeiro requisito para validade de qualquer convenção processual, desta feita, é ter sido firmado em hipótese na qual se debate sobre direito que admite autocomposição. A lei é taxativa, e em uma interpretação literal, não resta espaço para convenções processuais quando se trata de direitos que não admitem autocomposição (ou direitos indisponíveis), os quais se configuram, conforme Bastos (apud MOUZALAS; ATAÍDE JÚNIOR, 2015, p. 409), quando "o seu titular não puder se privar dele por simples ato de vontade", seja por determinação legal, seja porque sua natureza o torna inalienável.

Há opiniões, todavia, em sentido contrário. Afirma Greco (2007), por exemplo, que os titulares de direitos indisponíveis não estão impedidos de firmar tal negócio processual com a 
parte adversa, "mas apenas que não podem praticar os [atos] que, direta ou indiretamente, possam prejudicar ou dificultar a tutela desses direitos".

Em posicionamento intermediário e mais moderado, Macêdo e Peixoto (2016, p. 123) aduzem que não é vedada a inversão convencional em processos que versam sobre direitos indisponíveis, "[...] mas tão-somente a inversão nesses casos contra o titular do direito em questão". Ou seja, as partes podem convencionar sobre a distribuição do ônus probatório mesmo debatendo sobre direito indisponível, desde que em favor do titular de tal direito, caso em que não haverá nulidade.

$\mathrm{O}$ segundo requisito é relativo ao equilíbrio entre as partes e à paridade de armas; a convenção exige consentimento, o qual exige, conforme Godinho (apud QUEIROZ, 2014), capacidade, voluntariedade e informação. Em suma, como aduz Greco (2007), o ato deve ser livre, por não resultar de coação ou intimidação, e consciente, implicando ciência e entendimento de que o ato poderá redundar em prejuízo processual futuro, cabendo a ele aquilatar os prós e contras de tal decisão. A convenção processual exige, ainda, um equilíbrio real e concreto entre as partes, e não apenas formal, especialmente quando há relação de dependência de uma parte em relação à outra ou inferioridade econômica que possa criar uma desigualdade irrazoável.

O terceiro requisito, por fim, é referente à observância dos princípios processuais e garantias fundamentais. Para Macêdo e Peixoto (2016, p. 120-121), a conveniência do Judiciário deve ser levada em conta, a fim de evitar que as partes optem por um procedimento atípico e custoso, desarrazoado ou incompatível com o volume de trabalho do órgão jurisdicional. Além disso, o juiz não pode admitir acordo processual que afaste a boa-fé processual ou o dever de cooperação, expressões indisponíveis do devido processo legal. A respeito, dispõe o Enunciado n. 407 do Fórum Permanente de Processualistas Civis: "Nos negócios pro- 
cessuais, as partes e o juiz são obrigados a guardar nas tratativas, na conclusão e na execução do negócio o princípio da boa-fé".

Nessa linha, para Greco (2007), são expressões de princípios indisponíveis e, por consequência, características inafastáveis por meio de convenções processuais: independência, a imparcialidade e competência absoluta do juiz ${ }^{3}$; capacidade das partes; liberdade de acesso à tutela jurisdicional em igualdade de condições por todos os cidadãos (igualdade de oportunidades e de meios de defesa); procedimento previsível, equitativo, contraditório e público; concorrência das condições da ação; delimitação do objeto litigioso; respeito ao princípio da iniciativa das partes e ao princípio da congruência; conservação do conteúdo dos atos processuais; possibilidade de ampla e oportuna utilização de todos os meios de defesa, inclusive a defesa técnica e a autodefesa; intervenção do Ministério Público nas causas que versam sobre direitos indisponíveis; controle da legalidade e causalidade das decisões judiciais através da fundamentação; celeridade do processo, especialmente à luz do inciso LXXVIII do art. $5^{\circ}$ da Constituição Federal de 1988; e garantia de uma cognição adequada pelo juiz, um dos objetivos essenciais da atividade processual.

Além de tais requisitos, especificamente com relação à convenção processual sobre distribuição do ônus probatório, dispõe o art. $373, \S 3^{\circ}$, do CPC/2015, anteriormente citado, acerca de mais duas restrições para a validade da convenção processual sobre distribuição do ônus probatório: o acordo não pode "recair sobre direito indisponível da parte" (inciso I) - previsão legal em que, na verdade, repete, com outras palavras, a restrição já constante no caput do art. 190 - ; e também não pode o negócio processual "tornar excessivamente difícil a uma parte o exercício do direito" (inciso II), hipótese que está relacionada ao

3 Reza o Enunciado n. 20 do Fórum Permanente de Processualistas Civis: "Não são admissíveis os seguintes negócios bilaterais, dentre outros: acordo para modificação da competência absoluta, acordo para supressão da primeira instância”. 
equilíbrio entre as partes e à necessidade de respeito ao princípio do devido processo legal e às garantias constitucionalmente previstas relacionadas ao processo judicial, antes comentados.

Por fim, no caso específico em que a demanda envolve Direito consumerista, revela-se impossível a convenção processual que inverter o ônus da prova em desfavor do consumidor, em face da especial previsão do art. 51, VI, do CDC, no sentido de que cláusula com tal previsão é "nula de pleno direito".

Quanto à hipótese de invalidade da avença, é indubitável que ao magistrado incumbe zelar pela correição do acordo e negar-lhe aplicação quando não preencher os requisitos legais. Macêdo e Peixoto (2016, p. 127) afirmam que o autorregramento só é possível em relação a situações que se encontram no âmbito de disposição das partes; por isso é que elas não podem dispor sobre os poderes (ou deveres) do magistrado. Inadmissível, assim, hipoteticamente, um negócio processual que, a pretexto de regulamentar a distribuição do ônus probatório, impeça o magistrado de conhecer determinada espécie de prova, ou tente limitar a análise judicial à determinada prova em específico.

Assim, se, por um lado, como afirmam Mouzalas e Ataíde Júnior (2015, p. 415), a convenção sobre ônus probatório possui basicamente duas consequências (quais sejam, a alteração da atuação probatória das partes e a modificação de quem arcará com os riscos de não se desincumbir do ônus da prova), por outro lado, a invalidação do negócio jurídico processual acarretará o retorno do ônus a quem deve ele pertencer - seja distribuído conforme a teoria estática, ou conforme a teoria dinâmica.

Isso significa que, se o juiz conhece acerca da convenção e define queela não obedeceu aos requisitos legais, será necessário que seja estabelecido sobre quem recairá o ônus probatório como se o acordo não existisse; e, para isso, o julgador necessariamente revisitará a teoria estática (como regra geral 
do sistema processual) ou a teoria dinâmica (se o caso concreto recomendar sua incidência). Em qualquer caso, todavia, há de ser respeitada o contraditório, de modo a possibilitar que a parte a quem inicialmente não recairia o ônus tenha a oportunidade processual de dele se desincumbir.

\section{CONCLUSÃO}

O cerne do trabalho ora apresentado é a análise da possibilidade de as partes de um processo judicial, mediante convenção processual, regulamentarem a distribuição do ônus probatório, especificando sobre quem ele recairá e que aspectos da prova a negociação abrange.

Após o estudo, é possível verificar que o legislador, ao inserir na nova lei processual o instituto da teoria dinâmica do ônus probatório de modo subsidiário - ou seja, estabelecendo a teoria estática como regra geral, mas permitindo que o juiz, no caso concreto, faça recair sobre a outra parte tal ônus, desde que presentes certos requisitos legais - atendeu anseios da doutrina, de longa data. Isso porque a natural evolução da sociedade já não mais se adequava a uma regra estanque e inalterável sobre o ponto em questão.

Assim, embora já possível, no regramento processual anterior, que as partes convencionassem sobre a distribuição, entre si, do ônus probatório, tal instituto era praticamente inexistente na vida prática, relegando-se a uma previsão legal de uso meramente teórico. Por outro lado, com o atual diploma processual civil, o ponto ganhou novos contornos, seja pela nova regulamentação da convenção processual em geral, seja pela previsão legal da distribuição dinâmica do ônus da prova, seja ainda pelo princípio da cooperação, que orienta todo o Processo Civil.

Concluindo, infere-se que há possibilidade de incremento da utilização da convenção processual sobre o ônus da prova, 
pelo que o juiz deverá, inicialmente, estar atento aos requisitos legais de validade da negociação, especialmente verificando se o direito material discutido no processo admite a convenção, bem como, se encontram-se presentes todos os requisitos legalmente exigidos. E, no caso de verificar sua falta, declarar, desde logo, respeitados os princípios do contraditório e da ampla defesa, sua invalidade, adequando, em seguida, a distribuição do ônus probatório, conforme a regra geral (teoria estática) ou excepcional (teoria dinâmica), de acordo com as nuances do caso concreto e as balizas legais.

\section{REFERÊNCIAS}

BAZZANEZE, Thaís. Distribuição dinâmica dos ônus probatórios: análise à luz do devido processo legal e do acesso à justiça. Revista de Processo, São Paulo, v. 37, n. 205, p. 55-88, mar. 2012.

BRASIL. Código de defesa do consumidor (1990). Disponível em: http://www.planalto.gov.br/ccivil_03/leis/18078.htm. Acesso em: 8 maio 2019.

BRASIL. Código de processo civil (1973). Disponível em: http:/www.planalto.gov. br/ccivil_03/leis/15869impressao.htm. Acesso em: 8 maio 2019.

BRASIL. Código de processo civil (2015). Disponível em: http:/www.planalto.gov. br/ccivil_03/_Ato2015-2018/2015/Lei/L13105.htm. Acesso em: 8 maio 2019.

BRASIL. Lei n. 7.347 (1985). Disponível em: http://www.planalto.gov.br/ccivil_03/ leis/17347orig.htm. Acesso em: 8 maio 2019.

BRASIL. Superior Tribunal de Justiça. Agravo no Recurso Especial n. 1.450.473/SC. Rel. Min. Mauro Campbell Marques, Segunda Turma, j. 23/9/2014, DJe 30/9/2014. Disponível em: http://www.planalto.gov.br/ccivil_03/leis/17347orig.htm. Acesso em: 8 maio 2019.

BRASIL. Superior Tribunal de Justiça. Recurso Especial n. 972.902/RS. Rel. Min. Eliana Calmon, Segunda Turma, j. 25/8/2009, DJe14/9/2009. Disponível em: http:// www.planalto.gov.br/ccivil_03/leis/17347orig.htm. Acesso em: 8 maio 2019.

BRASIL. Superior Tribunal de Justiça. Recurso Especial n. 1.286.704/SP. Rel. Min. Nancy Andrighi, Terceira Turma, j. 22/10/2013, DJe 28/10/2013. Disponível em: http:// www.planalto.gov.br/ccivil_03/leis/17347orig.htm. Acesso em: 8 maio 2019.

CAMBI, Eduardo. Teoria das cargas probatórias dinâmicas (distribuição dinâmica do ônus da prova): exegese do art. $373, \S \S 1^{\circ}$ e $2^{\circ}$ do NCPC.In: DIDIER JR, Fredie (coord.). Direito probatório. 2. ed. Salvador: Juspodivm, 2016.

FÓRUM PERMANENTE DE PROCESSUALISTAS CIVIS. Enunciados do fórum permanente de processualistas civis. DIDIER JR, Fredie; MAZZEI, Rodrigo Reis (coord.). Vitória, 2015. Disponível em: http:/civileimobiliario.web971.uni5.net/wp-content/uploads/2017/07/Carta-de-Florian\%C3\%B3polis.pdf. Acesso em: 8 maio. 2019. 
GODINHO, Robson Renault. Negócios processuais sobre o ônus da prova no novo código de processo civil. São Paulo: Revista dos Tribunais, 2015.

GRECO, Leonardo. Os atos de disposição processual: primeiras reflexões. In: Revista Eletrônica de Direito Processual, Rio de Janeiro, v. 1, n. 1, out./dez. 2007. Disponível em: http://www.e-publicacoes.uerj.br/index.php/redp/article/view/23657/16714. Acesso em: 8 maio 2019.

LOURENÇO, Haroldo. Teoria dinâmica do ônus da prova no novo CPC. São Paulo: Método, 2015.

MACÊDO, Lucas Buril de; PEIXOTO, Ravi. Ônus da prova e sua dinamização. 2. ed. Salvador: Juspodivm, 2016.

MOUZALAS, Rinaldo; ATAÍDE JÚNIOR, Jaldemiro Rodrigues de. Distribuição do ônus da prova por convenção processual. In: Revista de Processo,São Paulo: RT,v. 40, n. 240 , p. 399-423, fev. 2015.

PACÍFICO, Luiz Eduardo Boaventura. O ônus da prova. 2. ed. São Paulo: Revista dos Tribunais, 2011.

PAOLINELLI, Camilla Mattos. O ônus da prova no processo democrático. Rio de Janeiro: Lumen Juris, 2014.

PONTE, Marcelo Dias; ROMÃO, Pablo Freire. Negócio jurídico processual e flexibilização do procedimento: as influências da autonomia privada no paradigma publicista no direito processual civil. In: Revista Eletrônica de Direito Processual, Rio de Janeiro, v. 16, n. 16, jul./dez. 2015. Disponível em: http://www.e-publicacoes.uerj.br/index. php/redp/article/view/19968. Acesso em: 8 maio 2019.

QUEIROZ, Pedro Gomes de. Convenções disciplinadoras do processo judicial. In: Revista Eletrônica de Direito Processual, Rio de Janeiro, v. 13, n. 13, jan./ jun. 2014. Disponível em: http:/www.e-publicacoes.uerj.br/index.php/redp/article/ view/11931/9343. Acesso em: 8 maio 2019.

SANTA CATARINA. Tribunal de Justiça. Resolução do Conselho da Magistratura n. 5 , de 8 de abril de 2019. Institui o Sistema Eletrônico de Assistência Judiciária Gratuita e estabelece os valores de honorários de peritos, tradutores, intérpretes e defensores dativos no âmbito do Poder Judiciário do Estado de Santa Catarina. Diário da Justiça Eletrônico n. 3036, 9 abr. 2019, p. 13-14.

SANTA CATARINA. Tribunal de Justiça. Súmula n. 26. Diário da Justiça Eletrônico n. 1953,9 set. 2014 , p. 1.

SANTOS, Sandra Aparecida de Sá dos. A inversão do ônus da prova. 2. ed. São Paulo: Revista dos Tribunais, 2006.

SILVEIRA, Bruno Braga da. A distribuição dinâmica do ônus da prova no CPC-2015. In: DIDIER JR, Fredie (coord.). Direito probatório. 2. ed. Salvador: Juspodivm, 2016.

Recebido em: 27/04/2019

Aprovado em: 30/07/2019 